\title{
The Effect of Problem Based Learning and Learning Motivation of Mathematical Problem Solving Skills of Class 5 Students at SDN 0407 Mondang
}

\author{
Arif Mahmuda Pohan', Asmin ${ }^{2}$, Asih Menanti \\ ${ }^{1}$ Postgraduate Basic Education Student, Medan State University, Indonesia \\ ${ }^{2}$ Postgraduate Basic Education Lecturer, Medan State University, Indonesia \\ mahmudapohan@gmail.com
}

\section{Abstract}

This study aims to: 1) find out whether students' mathematical problem solving abilities that are taught with problem based learning are better than students who are taught by direct learning. 2) find out whether the mathematical problem solving ability of students who have high learning motivation is better than students who have low learning motivation. 3) find out whether there is an interaction between learning and student learning motivation towards students' mathematical problem solving abilities. This study uses a quasi-experimental method with a $2 \times 2$ factorial design. The study population was fifth grade students (five) in the odd semester of the 2017/2018 Academic Year at SDN 0407 Mondang which consisted of two classes with a sample of 50 students. The class used as the sample of the experimental group is class $V A$ with 25 students and the control class is class $V B$ with 25 students. Thus the sample selection is done by total sampling technique. Data was collected by student achievement test and student motivation instrument. The collected data was processed statistically using a two-way variance (anava) analysis technique with a significance level of 0.05 . The results showed that (1) There was an influence of problem-based learning methods on the mathematical problem solving ability of Class V students of SD Negeri 0407 Mondang 2017/2018 Academic Year; (2) There is an influence of student learning motivation on the mathematical problem solving ability of fifth grade students of SD Negeri 0407 Mondang for the Academic Year 2017/2018; and (3) There is an interaction between problem-based learning methods and students' motivation to the mathematical problem solving ability of students of Class V of SD Negeri 0407 Mondang 2017/2018 Academic Year. Practically, this study recommends that teachers use problembased learning methods in mathematics learning and pay attention to the level of student motivation so that the learning design is adjusted to that motivation level. Theoretically, this study contributes to adding knowledge related to problem-based mathematics learning in elementary schools. Further studies can deepen studies related to the suitability of student characteristics with the selected learning method because these aspects are indicated as one of the key factors for student learning success.

Keywords

PBL method; learning motivation; problem solving; mathematics

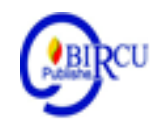

\section{Introduction}

At school, from elementary to secondary school or even college, students undergo, practice, and experience the learning process of various knowledge and skills. With this provision, it is hoped that in the future they will be able to develop their potential so that they 
become intelligent, productive, reliable, resilient and useful members of society by contributing their energy and thoughts to solve problems that will always arise wherever they are. For this reason, especially in wading through life in the future which is laden with uncertainty, competition between nations is getting sharper, changes are so fast in almost all aspects, and problems faced are increasingly complex then during undergoing an educational process, it is important students are given the experience of completing various problems (Napitupulu, 2011).

One of the mathematical skills that students must possess and achieve is problem solving. Problem solving is very close to mathematical characteristics. Problem solving (problem solving) is a process carried out to reach logical conclusions based on knowledge relating to facts and various relevant sources. Problem solving activities must be done by students, if they do not do the activity of thinking while learning, then what they get is just memorization and does not understand the core or concept of the material that has been learned. With the existence of problem solving activities when learning, students will arrive at the correct conclusions about the material being studied because it has gone through a logical thinking process when learning.

Until now mathematics was still considered a difficult, boring, even scary subject. This assumption may not be excessive in addition to having an abstract nature, a good understanding of mathematical concepts is very important because to understand the new concepts required preconditions of understanding the previous concepts. While from the teacher's side, the teacher is required to choose the right learning approach in accordance with the material presented in order to achieve the learning objectives.

Thus, learning mathematics becomes more meaningful (meaningfull), students not only learn to know something (learning to know about), but also learn to do (learning to do), learn to animate (learning to be), and learn how they should learn (learning to learn), and learning to socialize with friends and the environment (learning to live together).

However, the facts in the TIMSS evaluation report (The Trends of Mathematical and Science Studies) in 1999, 2003, and 2007 show that students' mathematical problem solving abilities are in the low category (Wilson, 2000) in Napitupulu (2011). The TIMSS (The Trends of Mathematical and Science Studies) and PISA (Program for International Student Assessment) studies show that the mathematical abilities of Indonesian students are still below international standards. The latest TIMSS results in 2011 ranked Indonesia 38th out of 42 countries (HSRC \& IEA, 2012) and even the latest PISA results were even more alarming, Indonesia ranked 64th out of 65 countries (OECD, 2013). Other references that indicate students' weaknesses in mathematical problem solving abilities can be seen in the research conducted by Amir (2014), Previous similar results were also found in Napitupulu (2008), Permana and Sumarmo (2007) and Suryadi (2005).

The foregoing can be realized, if the teacher in his learning can: (1) provide opportunities for students to establish meaningful cooperation with friends and teachers; (2) encouraging and triggering students to find new and innovative things; (3) allows students to learn in a free, stressful, psychologically and physically involved manner; (4) exposes students to problems, dilemma problems, the answers of which require creativity and new possibilities according to the level of students' cognitive development; (5) encouraging and encouraging students to achieve achievements, compete, dare to express and actualize themselves with subject matter; and (6) using methods that are tailored to the characteristics of students and subjects, which include the process of exploration, elaboration, and confirmation. 
The above description shows that the problem solving approach is the focus in learning mathematics. To improve the ability to solve problems, skills need to be developed to understand problems, create mathematical models, solve problems, and interpret solutions. Thus, in learning mathematics, teachers should start learning mathematics with an introduction to problems that are appropriate to real situations or contextual problems. By proposing this contextual problem, students are gradually guided to master mathematical concepts.

Moving on from the background that has been conveyed and supported by preliminary studies that have been conducted, researchers assume that problem-based learning is an approach or model that is very much in line with the content standards and mathematical process standards as mandated in Permendiknas number 22 of 2006 concerning process standards education.

The objectives of this study are: 1) To find out the mathematical problem solving abilities of students who are taught with problem based learning better than students who are taught by direct learning. 2) To find out the mathematical problem solving ability of students who have high learning motivation better than students who have low learning motivation. 3) To find out whether there is an interaction between learning with student learning motivation towards students' mathematical problem solving abilities.

\section{Review of Literature}

\subsection{Problem Based Learning}

According to Dewey, in Trianto (2011: 91) learning based on problems is the interaction between stimulus and response, a relationship between two directions of learning and the environment. The environment provides input to students in the form of assistance and problems, while the brain's nervous system functions to interpret such assistance effectively so that the problems faced can be investigated, assessed, analyzed, and the solutions sought well. Students' experience gained from the environment will make them materials and materials to gain understanding and understanding and can be used as guidelines and learning objectives.

\subsection{Direct Learning}

Direct learning is a teaching model that is teacher center. According to Arends (1997) in Trianto (2011: 41) direct learning model is one of the teaching approaches specifically designed to support student learning processes related to declarative knowledge and wellstructured procedural knowledge that can be taught with a pattern of activities that are gradual, one step by step. In addition the direct learning model is also intended to help students learn basic skills and obtain information that can be taught step by step.

\subsection{Problem Solving Ability}

Polya, in Napitulu (2011: 34) emphasized that problem solving is a typical achievement of the intelligence and intelligence of special talents from humans. He added, education should contribute to the development of intelligence (intelligence). For this reason in school, mathematics lessons should be the biggest contribution in the development of this intelligence. That's because mathematically provides a way, opportunity, and experience for children to solve problems scientifically. 


\subsection{Motivation}

Motivation is a psychological process that can explain a person's behavior, behavior is essentially an orientation towards a goal. Many motivational theories are based on the principle of need or (need). Needs that cause someone trying to be able to fulfill it. To achieve these objectives requires the process of interaction of several elements. Thus, motivation is the force that drives someone to do something to achieve the goal. These forces are basically stimulated by the existence of various needs, such as: (1) the desire to be fulfilled, (2) behavior, (3) objectives, (4) feedback.

So it can be concluded that motivation is an impulse that causes a person to behave and cause an energy change that exists in humans, so that it will have an impact with psychological problems, feelings and also emotions to then act and do something.

\subsection{Learning Motivation}

Uno (2013: 23) states that "learning motivation is internal and external encouragement to students who are learning to make changes in behavior". Likewise in mathematical lessons in order to achieve maximum results there must be motivation to learn. When students' motivation to learn is high, teaching and learning activities tend to increase in the sense that learning will be active and students who learn will truly follow the teaching and learning process so that the expected learning objectives can be achieved.

\section{Research Method}

This study uses a quasi-experimental method with a $2 \times 2$ factorial design. The study population was students in class V (five) in the odd semester of the 2017/2018 Academic Year at SDN 0407 Mondang which consisted of two classes with a sample of 50 students. The class that was sampled as the experimental group was class V A with 25 students and the control class was class V B with 25 students. Thus the sample selection is done by total sampling technique. Data was collected by student achievement test and student motivation instrument. The collected data was processed statistically using a two-way variance (anava) analysis technique with a significance level of 0.05 .

\section{Discussion}

\subsection{Mathematical Problem Solving Ability Using Problem Based Learning Methods}

Table 1. Frequency Distribution of Students' Problem Solving Abilities with PBL Learning Methods (Experimental Class)

\begin{tabular}{cccc}
\hline No. & Score & Frequency & Percentage \\
\hline 1 & $<=70$ & 5 & 20 \\
\hline 2 & $71-75$ & 6 & 24 \\
\hline 3 & $76-80$ & 8 & 32 \\
\hline 4 & $81-85$ & 4 & 16 \\
\hline 5 & $86-90$ & 2 & 8 \\
\hline \multicolumn{2}{c}{ Total } & 25 & 100.0 \\
\hline Average & 78,4 & \\
\hline \multicolumn{2}{c}{ St. Deviation } & 6,075 & \\
\hline
\end{tabular}




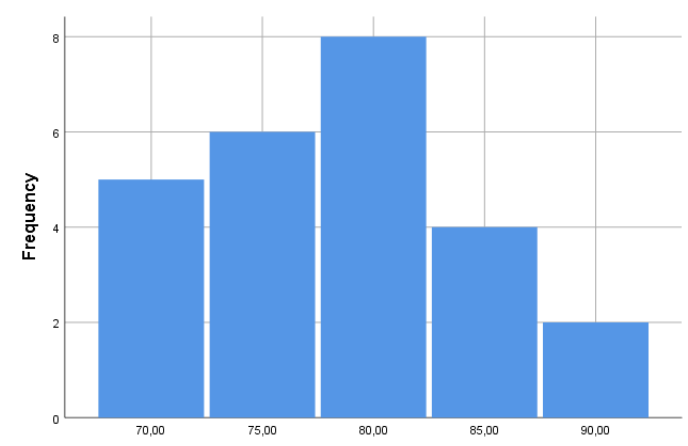

Figure 1. Histogram of Students Mathematical Problem Solving Abilities Using Problem Based Learning Methods

\subsection{Mathematical Problem Solving Capabilities Using the Ordinary Learning Model}

Table 2. Frequency Distribution Students' problem solving abilities with the Ordinary Learning Method

\begin{tabular}{cccc}
\hline No. & Score & Frequency & Percentage \\
\hline 1 & $\leq 60$ & 3 & 12 \\
\hline 2 & $61-65$ & 6 & 24 \\
\hline 3 & $66-70$ & 8 & 32 \\
\hline 4 & $71-76$ & 6 & 24 \\
\hline 5 & $77-80$ & 2 & 8 \\
\hline \multicolumn{2}{c}{ Total } & 25 & 100.0 \\
\hline Rata-rata & 71,97 \\
\hline St. Deviasi & 5,75 \\
\hline
\end{tabular}

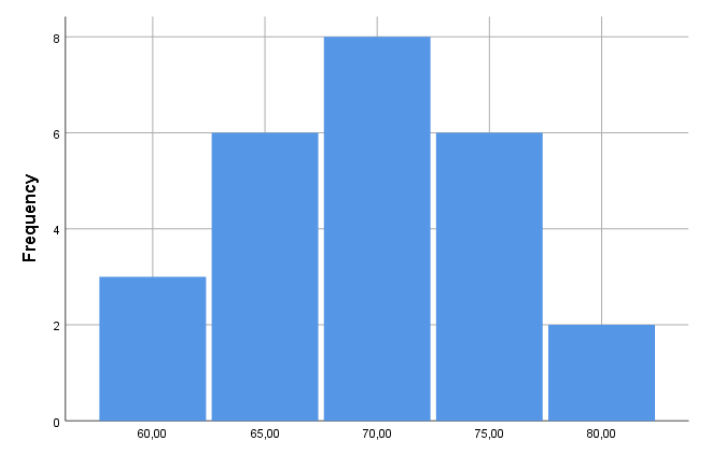

Figure 2. Histogram Mathematical problem solving abilities of students who use the ordinary learning methods 
4.3 Mathematical problem solving abilities of High Motivation Students

Table 3. Frequency Distribution of the Problem Solving Ability of Students with High Motivation

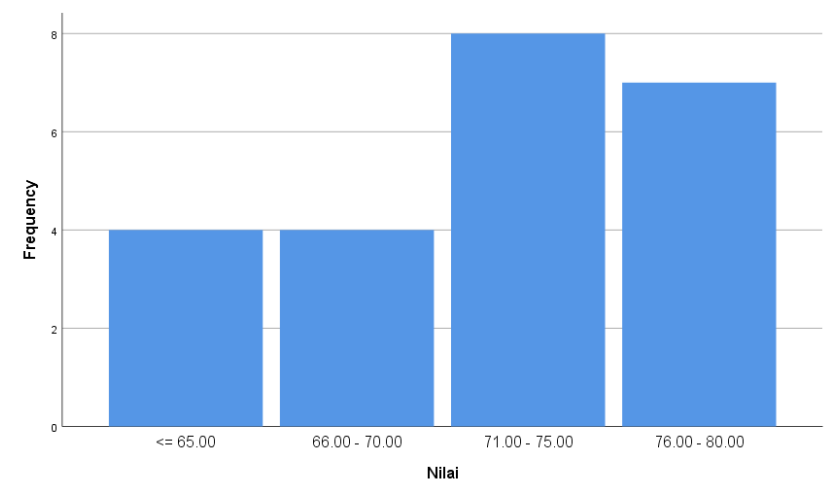

Figure 3. Histogram Mathematical problem solving abilities of students who have high motivation

\subsection{Mathematical Problem Solving Ability of Students with Low Motivation}

Table 4. Frequency Distribution Problem solving abilities

\begin{tabular}{|c|c|c|c|}
\hline No. & Score & Frequency & Percentage \\
\hline 1 & $\leq 60$ & 3 & 11.1 \\
\hline 2 & $61-65$ & 7 & 25.9 \\
\hline 3 & $66-70$ & 12 & 44.4 \\
\hline 4 & $71-75$ & 4 & 14.8 \\
\hline 5 & $76-80$ & 1 & 3.7 \\
\hline \multicolumn{2}{|c|}{ Total } & 27 & 100.0 \\
\hline \multicolumn{2}{|c|}{ Average } & 68,7 & \\
\hline \multicolumn{2}{|c|}{ St. Deviation } & 4,92 & \\
\hline
\end{tabular}

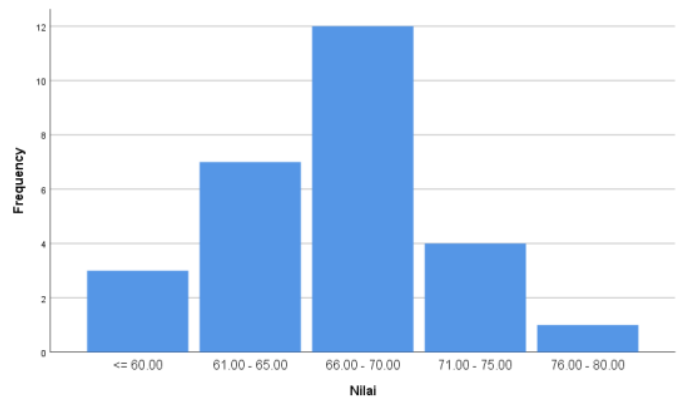

Figure 4. Histogram Mathematical problem solving abilities of students who have low motivation 


\subsection{ANAVA Statistics Testing}

Table 5. Descriptive Statistics of Research Data

\begin{tabular}{|c|c|c|c|c|}
\hline \multirow[b]{2}{*}{ Motivation } & \multirow[b]{2}{*}{ Indicator } & \multicolumn{2}{|c|}{ Learning methods } & \\
\hline & & $\begin{array}{c}\text { Problem Based } \\
\text { Learning }\end{array}$ & Conventional & \\
\hline \multirow{4}{*}{ High } & & & & Total \\
\hline & Average & 77,69 & 69 & 73,91 \\
\hline & St. Deviation & 2,59 & 3,94 & 5,43 \\
\hline & $\mathrm{N}$ & 13 & 10 & 23 \\
\hline \multirow{3}{*}{ Low } & Average & 72,5 & 65,67 & 68,7 \\
\hline & St. Deviation & 3,37 & 3,72 & 4,92 \\
\hline & $\mathrm{N}$ & 12 & 15 & 27 \\
\hline \multirow{3}{*}{ Total } & Average & 75,2 & 67 & \\
\hline & St. Deviation & 3,95 & 4,08 & \\
\hline & $\mathrm{N}$ & 25 & 25 & \\
\hline
\end{tabular}

Based on the results of the analysis of Factorial ANAVA analysis 2 x 2 in the table above, it can then be explained an explanation of the results of the research hypothesis testing as follows:

1. There is an influence of problem-based learning methods on the mathematical problem-solving abilities of students of Class VSD Negeri 0407 Mondang 2018/2019 Academic Year. Based on the results of data calculations it can be seen that students using problem-based learning methods obtain an average value of mathematical problem solving ability of 75.2 , while mathematical problem solving abilities of students who use conventional learning methods obtain an average value of problem solving ability of 67 . The results of analysis of variance for both learning approaches show the F-calculated price of 37.618 is greater and the F-table price of 4.001 at the significant level $\alpha=0.05$ so that Ho is rejected at the significant level $\alpha$ $=0.05$. Thus it can be concluded that there is an influence of problem-based learning methods on the mathematical problem solving ability of students V SD Negeri 0407 Mondang 2018/2019 Academic Year.

2. There is an influence of student learning motivation on the mathematical problem solving ability of fifth grade students of SD Negeri 0407 Mondang 2018/2019 Academic Year. Based on the results of data calculations it can be seen that students with low learning motivation get an average value of mathematical problem solving ability of 68.7, while the mathematical problem solving ability of students with high learning motivation get an average score of mathematical problem solving ability of 73.91. The results of analysis of variance for both learning approaches show the Fcalculated price of 29.51 is greater and the F-table price of 4.0012 at a significant level $\alpha=0.05$ so that Ho is rejected at the significant level $\alpha=0.05$. Thus it can be concluded that there is an influence of student learning motivation on the mathematical problem solving ability of fifth grade students of SD Negeri 0407 Mondang 2018/2019 Academic Year. 
3. There is an interaction between problem-based learning methods and student motivation to the mathematical problem-solving abilities of students of Class $\mathrm{V}$ of SD Negeri 0407 Mondang 2018/2019 Academic Year. Based on the results of hypothesis testing in table 4.6 above obtained $\mathrm{F}$-count $=5.656$ and $\mathrm{T}$-table value $=$ 4.0012 with $\mathrm{dk}(1.56)$ at the level of $\alpha=0.05$. These results indicate that F-count> Ftable. Furthermore, based on further tests using the Tukey HSD test and Scheffe Test it is known that there are differences between groups of students with high motivation who are in the experimental class (category 4) with high motivation in the control class (category 3), groups of students with low motivation in the experimental class ( category 2), and low motivation in the control class (category 1) with sig. $<0.05$. So it can be concluded that there is an interaction between problem based learning methods and student motivation to the mathematical problem solving ability of Class V students of SD Negeri 0407 Mondang 2018/2019 Academic Year. So the second hypothesis is accepted.

\section{Conclusion}

From the results of the study we can get the following conclusions:

1. There is an effect of problem-based learning methods on the mathematical problem solving ability of students of Class V of SD Negeri 0407 Mondang Academic Year 2018/2019. The problem solving abilities of students who are taught using problem-based learning methods are better than the problem solving abilities of students who are taught with conventional learning methods by obtaining an average value of 75.2 darmatematisda average problem solving abilities of students taught with conventional learning models, namely 67.

2. There is an influence of student learning motivation on the mathematical problem solving ability of Class IV students of SD Negeri 0407 Mondang Academic Year 2017/2018. Students with high learning motivation are known to have better mathematical problem solving skills compared to students with low learning motivation. Students with high learning motivation get an average value of 73.91, higher than students with low learning motivation, which is 68.7 .

3. There is an influence of interaction between problem-based learning methods and student motivation to the mathematical problem-solving abilities of students of Class V SD Negeri 0407 Mondang 2018/2019 Academic Year.

\section{References}

Napitupulu, Elvis (2011). Pengaruh Pembelajaran Berbasis Masalah Atas Kemampuan Penalaran dan Pemecahan Masalah Matematis Serta Sikap Terhadap Matematika Siswa Sekolah Menengah Atas. Disertasi PPs UPI Bandung: Tidak dipublikasikan.

OECD. (2013). PISA 2012 Assessment and Analytical Framework : Mathematics, Reading, Science, Problem Solving and Financial Literacy.

Amir, Almira (2014). Kemampuan Penalaran dan Komunikasi Dalam Pembelajaran Matematika. Jurnal Logaritma; Vol II No. 01, Januari 2014. Pp. 18-33.

Amir, M. Taufiq. (2009). Inovasi Pendidikan Melalui Problem Based Learning. Jakarta: Kencana Prenada Media Group 
Permana, Yanto, \& Sumarmo, Utari (2007). Mengembangkan Kemampuan Penalaran dan Koneksi Matematik Siswa SMA Melalui Pembelajaran Berbasis Masalah. Jurnal Educationist, Vol. 1 No.2/ Juli 2007. pp.116-123. ISSN 1907-8838.

Arends, Richard (2008). Learning to Teach.Penerjemah : Helly Prajitno dan Sri Mulyani.

New York: McGraw Hill Company

Trianto.(2011). Model Pembelajaran Terpadu. Surabaya: Bumi Aksara. 